\title{
Knowledge and Attitude on Legalization of Abortion among Undergraduate Students
}

\author{
Ojha $\mathrm{S}^{1^{*}}$, Silwal $\mathrm{M}^{2}$ \\ ${ }^{1}$ Teaching assistant, ${ }^{2} \mathrm{Co}$-ordinator \\ College of Nursing Sciences, Gandaki Medical College, Lekhnath, Kaski, Nepal
}

\section{Keywords}

Attitude, Abortion, Knowledge,

Legalization, Undergraduates.

\author{
Corresponding author \\ *Ms Sujata Ojha \\ Teaching Assistant \\ College of Nursing Sciences \\ Gandaki Medical College \\ Lekhnath, Kaski \\ Email id: ojhasujata@gmail.com
}

\begin{abstract}
Background: Abortion is public health concern in many parts of the world and is also contentious issue with religious, moral, cultural and political dimensions. Awareness program has most essential role to prevent the unusual death of mothers in the world.
\end{abstract}

Objectives: To assess the knowledge and attitude on legalization of abortion among undergraduate students.

Methods: A cross-sectional descriptive research design was used for this study. Proportionate stratified sampling technique and simple random sampling technique was used to select the subjects. Total 90 students were chosen as a sample and structured self-administered questionnaire was used to collect data.

Results: The mean age of the respondents was 19.82. Most 58 $(64.40 \%)$ of the respondents were females; majority $76(84.40 \%)$ of the respondents were of upper caste group. Most 85 (94.4\%) of the respondents had adequate knowledge on legalization of abortion and majority 83 (94.30\%) of the respondents had positive attitude towards legalization of abortion. The study shows that the most knowledgeable area was on concept of abortion (88.55\%) and the least knowledgeable $(58.00 \%)$ area was on method of abortion. Factors like age, gender, residence and educational faculty were not found to be associated with knowledge on legalization of abortion.

Conclusions: Undergraduate students had good level of knowledge and attitude on legalization of abortion. Highest knowledge was present in concept of abortion and lowest in methods of abortion. More awareness program should be accessible to undergraduates in order to increase the level of knowledge.

\section{INTRODUCTION}

"Abortion: The guilt hurts more than labor" - Joshua Michael Levinson.

Abortion means ending of pregnancy by removal or forcing out from the womb or fetus or embryo before the age of viability $^{1}$. Induced abortion is the deliberate termination of pregnancy before the fetus attained viability i.e. become capable of independent extra-uterine life. Abortion is a public health concern in many parts of the world and is also contentious issue with religious, moral, cultural and political dimensions ${ }^{2}$. Abortion can occur spontaneously in which case it is often called a miscarriage. It can also be purposely caused which in case it is known as Induced 
abortion. The term abortion most commonly refers to the induced abortion of human pregnancy ${ }^{1}$.

Abortion was legalized in Nepal in 2002, the procedural under was passed in 2003 and the first CAC services was started at the Maternity Hospital, Kathmandu in March 2004. Two years later (April 2006) there were 122 approved facilities (76 Governmental organizations) located across the districts ${ }^{3}$. The abortion law allows women to terminate their pregnancy under the following conditions: Pregnancies of 12 weeks gestation or less for any woman on her own decision, pregnancies of 18 weeks gestation if the pregnancy is a result of rape or incest, and pregnancies of any duration with the recommendation of an authorized medical practitioner if the life of the mother is at risk, if her physical or mental health is at risk, or if the fetus is deformed. However, the law prohibits abortions done without the consent of the woman, sex selective abortions, and abortions performed outside the legally permissible criteria. If the girl is minor and when mother is mentally incompetent the consent of legal guardians is required to abort the pregnancy ${ }^{4}$.

Out of estimated 46 million pregnancies around the world that are terminated through induced abortion, about 19 million of them are outside the legal system according to World Health Organization (WHO). Most abortions occur in developing countries 33 million annually compared with seven million in developed countries, a disparity that largely reflects the relative population distribution ${ }^{5}$.

In developing countries as a whole it is estimated that five million women are admitted to Hospital for treatment of complications from induced abortions each year. This equates to an average rate of five to seven per 1000 women per year in all developing countries, excluding China ${ }^{6}$. Research studies conducted in United States have reported that higher rates of abortion occur among college aged women with $60 \%$ of unintended pregnancies among $20-24$ years old 7 .

It is estimated that among the total pregnancies each year in South and South-East Asia, about one third are unplanned pregnancies which leads to abortion. About $30 \%$ of pregnancies in Bangladesh, 21\% in India and 35\% in Nepal are unplanned that ultimately increases the rate of abortion ${ }^{8}$.

Even after the legalization of abortion in Nepal, unsafe abortion practices are prevalent in society. Sixty six percent of women receiving post abortion services in the Tertiary Hospitals choose unsafe abortion methods. Forty four percent of women do not have knowledge regarding the legalization of abortion ${ }^{9}$.

Conclusions: youth participation in creating awareness is an important implementation strategy of adolescent health. In this respect, undergraduate students in the University is the best place for providing the information related to their health where maximum number of adolescents are representing different areas as well background. Thus, providing information about abortion among the undergraduate students (most vulnerable group) is the best step for creating public awareness. In the context of Nepal, to access the youth the educational institution is regarded as a best source where target age group can be easily accessed.

\section{OBJECTIVES}

- To assess level of knowledge on legalization of abortion among undergraduate students.

- To determine the attitude towards legalization of abortion among undergraduate students.

- To find out the association between level of knowledge regarding legalization of abortion and selected demographic variables of undergraduate students.

\section{METHODS}

Descriptive cross sectional research design was employed to explore the knowledge and attitude regarding legalization of abortion among 90 undergraduate students of Health and Allied Sciences of Pokhara University. Proportionate stratified sampling technique was used in this study. The total population was divided into four strata and students were divided into proportion of $70 \%$ from each faculty. Lottery method of simple random sampling was used to select the samples. Data was collected using self-administered structured questionnaire. The research instrument was divided into three sections.

Section I: Socio demographics

Section II: Knowledge regarding abortion

Section III: Attitude towards abortion

For the validity of research pretesting of the instrument was done in 10 respondents in LA Grande International College, Reliability was maintained by using split half technique and obtained 0.93 . Official written permission was obtained from concerned authorities and Pokhara 
University before data collection. The data collection period was extended from 3 May 2014 (2071/1/20 BS) to 14 May 2014 AD (2071/1/31 BS). Written consent was taken voluntarily from the participant with assured confidentiality and anonymity. Selfadministered structured schedule was administered to assess the knowledge on legalization of abortion among undergraduates. Ethical clearance is obtained from Research Committee. Formal permission and approval sheet was obtained from college. SPSS version 16.0 was used for entering and tabulating data. Frequency and percentage was used to analyze socio-demographic characteristics. Descriptive statistics as mean, standard deviation and mean percentage was used to assess the level of knowledge on postnatal care. The association of level of knowledge with their selected demographic variables was analyzed by using Chi-square test.

\section{RESULTS}

\section{Organization and presentation of related data}

Section I: Description of demographic variables of undergraduates.

Section II: Level of knowledge on legalization of abortion among undergraduates.

Section III: Attitude level on legalization of abortion among undergraduates.

Section IV: Association of the level of knowledge on legalization of abortion with their selected demographic variables.

\section{Section I: Description of demographic variables of undergraduates}

Table 1: Socio-demographic characteristics of respondents $(\mathrm{n}=90)$

\begin{tabular}{lcc}
\hline \multicolumn{1}{c}{ Variables } & $\begin{array}{c}\text { Frequency } \\
\text { (f) }\end{array}$ & $\begin{array}{c}\text { Percentage } \\
\text { (\%) }\end{array}$ \\
Age & & \\
$\leq 20$ years & 73 & $81.10 \%$ \\
>20 years & 17 & $18.90 \%$ \\
$\begin{array}{l}\text { Gender } \\
\text { Males }\end{array}$ & 32 & $35.60 \%$ \\
Females & 58 & $64.40 \%$ \\
Ethnicity & & \\
$\begin{array}{l}\text { Upper caste religion } \\
\text { Others }\end{array}$ & 76 & $84.40 \%$ \\
& 14 & $15.60 \%$
\end{tabular}

\begin{tabular}{|c|c|c|}
\hline $\begin{array}{l}\text { Residence } \\
\text { Rural } \\
\text { Urban }\end{array}$ & $\begin{array}{l}16 \\
74\end{array}$ & $\begin{array}{l}17.80 \% \\
82.20 \%\end{array}$ \\
\hline $\begin{array}{l}\text { Type of family } \\
\text { Nuclear } \\
\text { Extended }\end{array}$ & $\begin{array}{l}80 \\
10\end{array}$ & $\begin{array}{l}88.80 \% \\
11.20 \%\end{array}$ \\
\hline $\begin{array}{l}\text { Family income } \\
\leq 35000 \\
\geq 35000\end{array}$ & $\begin{array}{l}59 \\
31\end{array}$ & $\begin{array}{l}65.60 \% \\
34.40 \%\end{array}$ \\
\hline $\begin{array}{l}\text { Marital status } \\
\text { Unmarried } \\
\text { Married }\end{array}$ & $\begin{array}{l}89 \\
01\end{array}$ & $\begin{array}{l}98.90 \% \\
01.10 \%\end{array}$ \\
\hline $\begin{array}{l}\text { Education Facult } \\
\text { BPH } \\
\text { BSc Nursing } \\
\text { BMLT } \\
\text { B. Pharm }\end{array}$ & $\begin{array}{l}30 \\
14 \\
17 \\
29\end{array}$ & $\begin{array}{l}33.30 \% \\
15.60 \% \\
18.90 \% \\
32.20 \%\end{array}$ \\
\hline $\begin{array}{l}\text { Source of } \\
\text { information } \\
\text { Radio/television } \\
\text { Family members } \\
\text { Friends } \\
\text { Health service } \\
\text { providers } \\
\text { Others }\end{array}$ & $\begin{array}{l}40 \\
06 \\
22 \\
06 \\
16\end{array}$ & $\begin{array}{l}44.40 \% \\
06.70 \% \\
24.40 \% \\
06.70 \% \\
17.80 \%\end{array}$ \\
\hline
\end{tabular}

Others=Dalit, Religious minorities, relatively

disadvantages Janajati, Relatively advantages Janajati

The data depicted in Table 1 shows that most 73 (81.10\%) of the respondents were $\leq 20$ years old and the mean age of the respondents was 19.82. Most $58(64.40 \%)$ of the respondents were females; majority $76(84.40 \%)$ of the respondents were of upper caste group whereas with regard to residence most $74(82.20 \%)$ of the respondents belong to urban area and majority $80(88.80 \%)$ of the respondents had nuclear type of family. With regards to family income (Rs/month), most 59 (65.60\%) of the respondents had family income of $\leq 35000$, majority 89 $(98.90 \%)$ of the respondents were unmarried and in terms of education faculty 30 (33.30\%) were of BPH, 29 (32.20\%) of B. Pharma, 17 (18.90\%) from BMLT and 14 (15.60\%) were from BSc Nursing students. Regarding the source of information most 40 (44.4\%) of the respondents got information from radio/TV.

Distribution of respondents based on knowledge on concept of abortion shows that most 56 (62.2\%) respondents had knowledge about abortion. Ninety $(100 \%)$ answered the correct meaning of safe abortion, $85(94.4 \%)$ mentioned the correct definition of illegal abortion. Majority 89 (98.9\%) of them had idea about the correct term for spontaneous abortion. Majority 79 
(87.80\%) knew that abortion is legal up to 12 weeks of gestation and majority 86 (95.60\%) had knowledge that abortion followed by sex selection of baby is illegal. Majority 85 (36.5\%) mentioned unmarried pregnancy is the most common cause of abortion.

Distribution of respondents based on knowledge regarding criteria required for abortion shows that majority 88 (97.80\%) mentioned that Government approved Hospitals/clinics are the best place for providing abortion services. Most 90 (41.90\%) said there should be trained health care providers. most 75 (33.8\%) mentioned knowledge on right to informed consent and right to privacy equally. Similarly, most 43 (47.8\%) had correct knowledge about abortion in ectopic pregnancy.

Distribution of respondents according to knowledge on laws regarding abortion: Majority 75 (83.30\%) had correct knowledge that a pregnant woman can terminate pregnancy on her own will up to 12 weeks of gestation. Seventy four $(82.2 \%)$ had knowledge that consent of women herself is only required for the termination of pregnancy up to 12 weeks of gestation and 66 (73.3\%) mentioned that consent of legal parents is required to undergo abortion in less than 16 years old. Majority 85 (94.4\%) are familiar that abortion can be done irrespective to gestational age, 41 (45.60\%) had mentioned correct knowledge about the time period for termination of pregnancy due to rape/incest. Similarly, majority 87 (96.7\%) had knowledge that consent of nearest guardian is required to procure abortion when pregnant women is mentally incompetent. Majority 79 (87.8\%) illustrates that without the will of pregnant women Government restrict abortion within 12 weeks of gestation.

Distribution of respondents according to knowledge on method of abortion: Data shows that, 60 (66.7\%) of respondents and 47 (52.2\%) of respondents had knowledge about method of abortion up to nine weeks and after nine weeks respectively. Similarly, 50 (55.6\%) of respondents correctly mentioned that six weeks is earliest period of gestation at which medical abortion can be done.

Distribution of respondents based on knowledge of complications of abortion: Data depicts that majority $89(98.9 \%)$ of the respondents correctly mentioned that heavy bleeding is the most common complication of unsafe abortion and most 53 (58.9\%) are not familiar with the complication of medical abortion.

Distribution of respondents based on knowledge on advices given after abortion procedure: The data shows that most $45(50 \%)$ of the respondents illustrates that after abortion ovulation will return back within one month time period, majority $70(77.8 \%)$ mentioned that IUCD cannot be used immediately after medical abortion, with regards to follow up after surgical abortion, 55 (61.1\%) correctly mentioned two weeks period for follow up. With regards to counseling to be provided to the women after abortion all of the respondents have some sort of knowledge, 84 $(41.4 \%)$ respondents said safe sexual practices.

Distribution of respondents based on knowledge regarding other questions related to abortion shows that with regards to advantages of legalization of abortion, most 85 (42.30\%) mentioned that unwanted pregnancy within criteria can be legally aborted, most 77 (36.70\%) with regards to disadvantages of legalization of abortion illustrates that they may ignore contraception as abortion is available for termination of pregnancy. Regarding the ways to make abortion safe, 82 (36.1\%) mentioned training health personnel to provide safe abortion services.

Knowledge aspect of respondents regarding legalization of abortion: Data shows that highest knowledge was in the area of concept of abortion with the mean percentage of 88.55 , with mean and SD of $7.97 \pm 0.99$. In the area of method for abortion, the mean percentage was 58.00 with mean and SD of $1.74 \pm 0.84$. Similarly, mean percentage in the area of laws regarding abortion was 80.42 with mean and SD $5.63 \pm 1$.16.mean percentage in the area of criteria required for abortion procedure, the mean percentage was 80.12 with mean and SD $6.41 \pm 1.03$. In the area of other questions related to abortion the mean percentage was 79.66 with mean and SD $7.17 \pm 1.53$. Similarly, about abortion procedure the mean percentage is 64.33 with mean and SD $3.86 \pm 1.06$. Moreover, in the area of complication of abortion the mean percentage is 62.00 with mean and SD $1.24 \pm 0.45$.

Attitude of respondents towards legalization of abortion: Data shows the frequency and percentage of respondent's attitude towards each statement. With regards to positive statements majority (83.3\%) respondents agreed that abortion is a reproductive right of women, (90.0\%) on any pregnancy can be legally aborted within 12 weeks of gestation, (83.3\%) on, if the girl is minor the consent of legal guardian is required to abort the pregnancy. Majority (63.3\%) agreed that legalization of abortion controls the population. Moreover, $(70.0 \%)$ agreed that abortion can be done irrespective to the gestational age when pregnancy risks the health of mother. With regards to negative statements most (64.4\%) 
disagreed that abortion can hinder women empowerment, $37.8 \%$ agreed that legalization of abortion allows youth to freely engage in sexual activities and $57.8 \%$ agreed that termination of pregnancy due to rape/incest shouldn't be limited up to 18 weeks. Likewise, $83.3 \%$ disagreed that complications of the induced abortion shouldn't be shared with other and $47.8 \%$ disagreed that if pregnancy risks the mother, abortion can be done without the consent of women.

Fig 1: Knowledge level of respondents on legalization of abortion

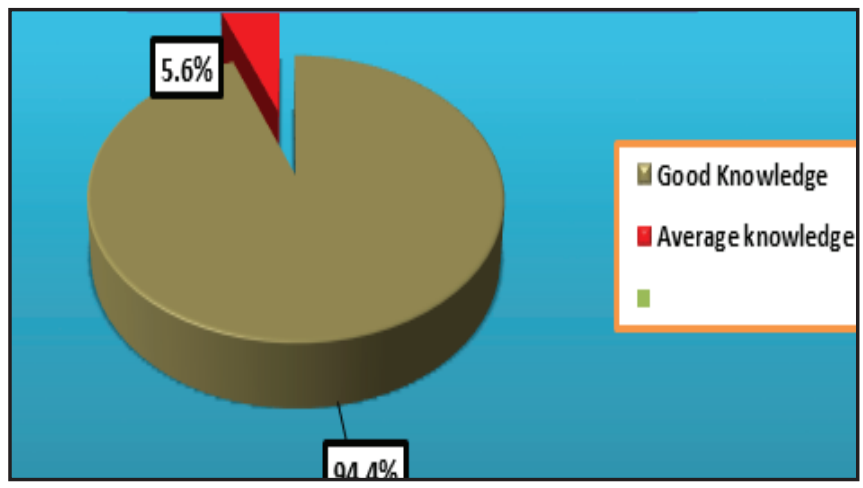

The data in Fig 1 illustrates that 85 (94.4\%) of the respondents had good level of knowledge on legalization of abortion, $05(05.60 \%)$ had average knowledge while nobody had poor knowledge on legalization of abortion.

Fig 2: Attitude level of respondents towards legalization of abortion

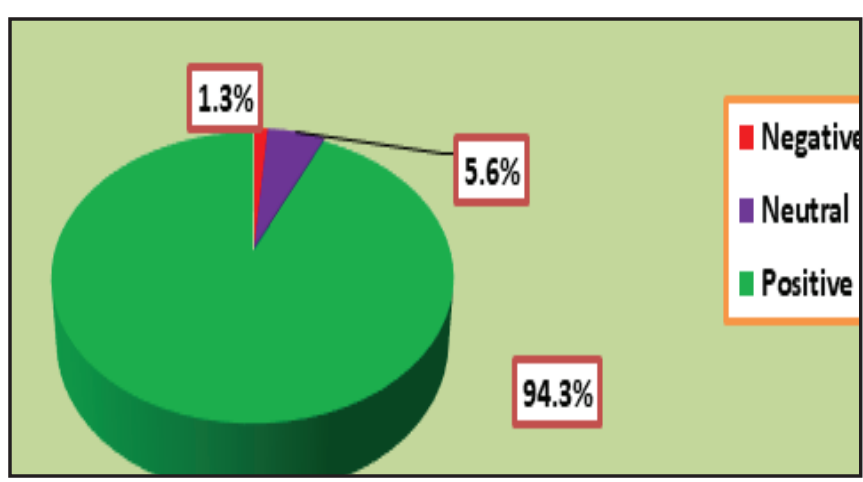

The data depicted in figure 2 explains that majority of the respondents $83(94.30 \%)$ had positive attitude towards legalization of abortion, $05(05.60 \%)$ had neutral and 02 $(01.30 \%)$ of respondents had negative attitude towards legalization of abortion.

\section{Section IV: Association of level of knowledge with their selected demographic variables}

Table 2: Association of level of knowledge with their selected demographic variables $(n=90)$

\begin{tabular}{|c|c|c|c|c|c|c|}
\hline \multirow[b]{2}{*}{ SN } & \multirow[b]{2}{*}{ Variables } & \multicolumn{2}{|c|}{ Total scores } & \multirow[b]{2}{*}{$\chi^{2}$ value } & \multirow[b]{2}{*}{ DF } & \multirow[b]{2}{*}{$\mathrm{p}$-value } \\
\hline & & $\begin{array}{c}\text { Median } \\
\leq 33\end{array}$ & $\begin{array}{c}\text { Median } \\
>33\end{array}$ & & & \\
\hline \multirow[t]{3}{*}{1} & Age in years & & & & & \\
\hline & $\leq 20$ years & 36 & 37 & & & \\
\hline & $>20$ years & 12 & 05 & 2.507 & 1 & $0.113 \mathrm{NS}$ \\
\hline \multirow[t]{3}{*}{2} & Gender & & & & & \\
\hline & Males & 20 & 12 & & & \\
\hline & Females & 28 & 30 & 1.676 & 1 & $0.195 \mathrm{NS}$ \\
\hline \multirow[t]{3}{*}{3} & Ethnicity & & & & & \\
\hline & Upper caste & 42 & 34 & & & \\
\hline & $\begin{array}{l}\text { group } \\
\text { Others }\end{array}$ & 06 & 08 & 0.731 & 1 & $0.393 \mathrm{NS}$ \\
\hline \multirow[t]{3}{*}{4} & & & & & & \\
\hline & Residence & 09 & 07 & & & \\
\hline & $\begin{array}{l}\text { Rural } \\
\text { Urban }\end{array}$ & 39 & 35 & 0.067 & 1 & $0.796 \mathrm{NS}$ \\
\hline \multirow[t]{3}{*}{5} & & & & & & \\
\hline & Type of family & 41 & 36 & & & \\
\hline & $\begin{array}{l}\text { Nuclear } \\
\text { Extended }\end{array}$ & 07 & 06 & 1.256 & 1 & $0.262 \mathrm{NS}$ \\
\hline \multirow[t]{7}{*}{6} & & & & & & \\
\hline & Education & 17 & 13 & & & \\
\hline & faculty & 06 & 08 & 6.137 & 3 & $0.197 \mathrm{NS}$ \\
\hline & $\mathrm{BPH}$ & 12 & 05 & & & \\
\hline & BSc Nursing & 19 & 10 & & & \\
\hline & $\begin{array}{l}\text { BMLT } \\
\text { B Pharm }\end{array}$ & & & & & \\
\hline & B. Pharm & & & & & \\
\hline
\end{tabular}

NS=Non significant; $\chi^{2} 2.706$ at 1 DF, 6.251 at 3 DF

Data represented on Table 2 reveals that there is no significant association between selected variables like age, gender, and ethnicity, type of family and education faculty.

\section{DISCUSSION}

In this study 85 (94.4\%) of the respondents had adequate level of knowledge on legalization of abortion. The result of our study was supported by the study conducted in Indian medical students in 27 different colleges in Maharashtra, India to assess the knowledge and attitude regarding abortion. The study reveals that $95.7 \%$ of students had very good knowledge regarding abortion ${ }^{11}$.

In present study majority 83 (94.30\%) of the respondents had positive attitude towards legalization of abortion. This finding was supported by the study conducted in Nepal to assess the knowledge and attitude about abortion among the adolescent students of higher secondary school. The study result shows that $60 \%$ of the respondents have positive attitude towards safe abortion and its legalization ${ }^{10}$. 


\section{CONCLUSIONS}

The results of the study showed that most 85 (94.4\%) of the respondents had adequate knowledge on legalization of abortion. The total score for knowledge level was 44 with the mean score of 34.05. Majority 83 (94.30\%) of the respondents had positive attitude towards legalization of abortion. The total score of attitude was 30 with the mean score of 24.48. Factors like age, gender, residence and educational faculty were not found to be associated with knowledge on legalization of abortion. The study shows that the most knowledgeable area (88.5\%) was on concept of abortion and the least knowledgeable area (58.50\%) was on method of abortion.

\section{Acknowledgement}

I would like to express my sincere gratitude to Pokhara University, School of Health and Allied Science for providing an opportunity to conduct this study. I would like to express heartfelt gratitude to the entire faculty members of BSc nursing program. Likewise, I would like to acknowledge all the respondents, without whose cooperation, this study would not be achievable.

\section{REFERENCES}

1. Grimes DA, Stuart G. Abortion jobber weekly: The need for better terminology. Contraception. 2010; 4(2): p. 93-96. Available from: http://dx.doi.org/10.1016/j. contraception.2009.09.005. PMID 20103443.

2. World Health Organization. Unsafe abortion; Nepal country profile. Kathmandu, Nepal. 2006. [cited on 2015 Apr 16]; Available from: www.who.int/ reproductive health/global monitoring/ RHRxmls/ $\mathrm{RH}$.

3. Ministry of health Nepal and center for research on environment health and population activities (CREHPA). 2007. Nepal comprehensive abortion care (CAC): National facility-based abortion study 2006: Summary report. Kathmandu: Ministry of Health and CREHPA.
4. Ministry of health and population. Annual report. Kathmandu: Government of Nepal, Department of Health and Services. 2011; 376.

5. Sedgh G, Singh S, Shah HI, Henshaw SK, Ahman E, Bankole A. Induced abortion: Incidence and trends worldwide from 1995 to 2008. The Lancet. 18 Feb 2012. 379(9816): 625-632. [cited on 2015 Apr 17].

6. Singh S. Hospital admissions resulting from unsafe abortion: Estimates from 13 developing Countries. The Lancet. 2006 Nov 25; 368(9550): 1887-1892.

7. Finer LB, Henshaw SK. Disparities in rates of unintended pregnancy in the United States 1994 and 2001. Perspective on Sexual and Reproductive Health. 2007; 38(2): 9396. [serial on the internet]. [cited on 2015 Apr 17]; Available from: http://onlinelibrary. wiley.com/doi/10.1363/3809006/pdf.

8. WHO. Global Health Observatory (GHO); Maternal and reproductive health. 2012 [cited on 2015 Apr 18] . Available from: http://www.who.int/gho/material health/en/index.html.

9. Bajracharya S. Safe abortion services, effectiveness to legalization to control teenage pregnancy. Aug 32014 [cited on 2015 Apr 15]. Available from: http://www. slideshare.net/ loveuappal/safe abortion-serviceseffectiveness-of legalization among teenage.

10. Bhandari SD, Poudyal SS. Knolwedge and attitude about abortion among adolescence students of higher secondary school. International Journal of Humanities and Social Studies. Feb 2015; 3(2): 1-5. [ISSN 23219203]. [cited on 2015 Jun 17]; Available from: http:// www.theijhss.com.10-HSIS02-020-updated.pdf.

11. Syden F. Knowledge and attitudes regarding abortion care among Indian medical students. Degree project, 2011 [cited on 2015 Apr 17]. Available from: www.divaportal.org/smash/ get/diva2:690325/ FULLTEXT01.pdf. 